\title{
Effect of Packaging and Antioxidant Combinations on Physicochemical Properties of Irradiated Restructured Chicken Rolls
}

\author{
Dong-Gyun Yim¹, Dong U. Ahn², and Ki-Chang Nam* \\ Department of Animal Science and Technology, Sunchon National University, Suncheon 540-950, Korea \\ ${ }^{1}$ Department of Health Administration and Food Hygiene, Jinju Health College, Jinju 660-757, Korea \\ ${ }^{2}$ Department of Animal Science, Iowa State University, Ames, IA 50011-3150, USA
}

\begin{abstract}
Effects of double packaging (combinational use of aerobic and vacuum conditions) and antioxidants on physicochemical properties in irradiated restructured chicken rolls were determined. Chicken breast treated with antioxidants (none, sesamol+a-tocopherol) was used to process restructured chicken breast rolls. The sliced rolls were vacuum, aerobic, or double packaged (vacuum for $7 \mathrm{~d}$ then aerobic for $3 \mathrm{~d}$ ) and electron beam irradiated at $2.5 \mathrm{kGy}$. Color, 2-thiobarbituric acid reactive substances (TBARS), oxidation reduction potentials (ORP), and volatile profiles of the samples were determined at 0 and $10 \mathrm{~d}$. Irradiation made restructured chicken rolls redder $(p<0.05)$, and the increased redness was more distinct in irradiated vacuum-packaged than irradiated aerobic or double packaged meats. TBARS values of antioxidant-treated double packaged rolls were lower than even nonirradiated vacuum-packaged meat, and those were distinct at $10 \mathrm{~d}(p<0.05)$. ORP and lipid oxidation values were lower in irradiated vacuum and double packaged samples than those in irradiated aerobic packaged ones at $0 \mathrm{~d}(p<0.05)$. Irradiation of restructured chicken rolls increased the amount of total volatiles. Considerable amounts of off-odor volatiles were reduced or not detected by double packaging and antioxidant treatment at $10 \mathrm{~d}$. Therefore, the combined use of antioxidants and double packaging would be useful to reduce redness and control the oxidative quality changes of irradiated restructured chicken rolls.
\end{abstract}

Key words: antioxidant, double-packaging, irradiated restructured chicken rolls, lipid oxidation, volatiles

Received March 5, 2015 / Revised March 26, 2015 / Accepted March 28, 2015

\section{Introduction}

Restructured meats are prepared from small cuts of meat to increase the yield of marketable product by using muscles of poor quality and trimmings. However, there are many risks to be contaminated to microbiological hazard during the processing of restructuring. The application of an HACCP-based approach as a method for the management of hazards of the food chain demonstrates the need for applying a cold decontamination treatment as a control measure in the production of foods which are to be marketed raw or minimally processed. Irradiation is such a control measure in the production of several types of raw or minimally processed foods such as poultry, meat and meat products (Molins et al., 2001).

Irradiation is one of the most effective technologies for

*Corresponding author: Ki-Chang Nam, Department of Animal Science and Technology, Sunchon National University, Suncheon 540-950, Korea. Tel: +82-61-750-3231, Fax: +82-61-7503230, E-mail: kichang@scnu.kr eliminating foodborne pathogens and improving the microbial safety of meat. WHO (1999) reported that irradiation technology has positive effects in preventing decay and improving the safety and shelf-stability of food products. The US FDA approved irradiation for red meats and poultry to control food-borne pathogens and extend the shelf-life of products (Gants, 1998). Although irradiating is the best method to ensure the microbiological safety of raw meat (Lambert et al., 1991), it caused a few radiolytic meat quality defects. Irradiated pork and poultry meat accelerated lipid oxidation (Ahn et al., 2000; KatusinRazem et al., 1992), produced a characteristic off-odor (Ahn et al., 2001; Patterson and Stevenson 1995), and developed a pink color (Lynch et al., 1991; Nam and Ahn, 2002). The major volatile compounds responsible for the characteristic off-odor in irradiated meats are sulfur compounds (Nam et al., 2003). Lipid oxidation is a special problem in irradiated meat when it is stored aerobically because oxygen is the most critical for lipid oxidation (Nam et al., 2003).

Packaging is a critical factor affecting quality of irradi- 
ated meat. The color and odor changes in irradiated meats also depended on packaging type. Modification of packaging methods can minimize the quality defect in irradiated meat (Nam et al., 2007). Exposing meat to aerobic conditions during irradiation and for certain periods of time during storage could help off-odor volatiles to escape from the meat (Nam and Ahn, 2003). They developed a modified packaging concept of "double packaging" in which the outer vacuum bag of doubly packaged meat (aerobically packaged and then vacuum-packaged doubly) were removed after a certain of storage to expose the samples under aerobic conditions. Double packaging maximized the elimination of off-odor volatiles from irradiated meat during storage (Nam et al., 2004). Therefore, an appropriate combination of aerobic- and vacuum-packaging conditions can be effective in minimizing both off-odor volatiles and lipid oxidation in irradiated restructured chicken meat.

Antioxidant additives are added to fresh and further processed meats to prevent oxidative rancidity, retard development of off-flavors, and improve color stability (Xiong et al., 1993). Certain antioxidants can interrupt free radical chain reactions by scavenging free radicals (Chen and Ahn, 1998) and using specific antioxidants can reduce lipid oxidation and off -odor formation by irradiation. Free radical scavengers (gallate, sesamol, and tocopherol), metal chelators (Trolox) and intrinsic antioxidant (carnosine), or their combinations can be used to reduce the production of off-odor volatiles in irradiated double-packaged chicken meats.

Although the effect of antioxidants have been demonstrated on controlling oxidative reactions in meat, very few studies have been done on the effects of double-packaging and antioxidant combinations on lipid oxidation and off-odor volatiles in irradiated restructured chicken meat. Therefore, this study was conducted to determine the effects of double-packaging and antioxidant combinations on color, lipid oxidation, and volatiles of irradiated restructured chicken.

\section{Materials and Methods}

\section{Processing and treatments}

Breast muscles from 6 chickens were pooled and used as a replication. Meats for each replication were ground through a $3-\mathrm{mm}$ plate and 4 replications were prepared. Five different treatments were prepared using antioxidant, packaging method, and irradiation conditions (Table 1). Vitamin E + sesamol combination was selected to use in this study because it was the most effective in reducing lipid oxidation and off-odor volatiles in irradiated turkey meat (Nam and Ahn, 2003). Sesamol (3,4-methylenedioxyphenol; Sigma Chemical Co., USA) plus a-tocopherol (Aldrich Chemical Co., USA) was mixed with the ground chicken meat at each 100 ppm level (final 200 ppm) using a bowl mixer (Model KSM 90; Kitchen Aid Inc., USA). Breast meats were ground through a $15-\mathrm{mm}$ plate twice, and then mixed with $2.0 \%$ of $\mathrm{NaCl}$ and $0.5 \%$ of polyphosphate (Brifisol 450 Super, BK Ladenburg Corp., USA) under vacuum for $3 \mathrm{~min}$. The mixture was stuffed into $150 \mathrm{~mm}$ collagen casings and then cooked in an $85^{\circ} \mathrm{C}$ smoke house with relative humility of $92 \%$ until the center temperature reached $74^{\circ} \mathrm{C}$. After cooling to room temperature by a cold-water shower, the rolls were cut into 10-mm thick slices and individually vacuum-packaged in high oxygen-barrier bags (nylon/polyethylene, $9.3 \mathrm{~mL}$ $\mathrm{O}_{2} / \mathrm{m}^{2} / 24 \mathrm{~h}$ at $0^{\circ} \mathrm{C}$ ), aerobically packaged in polyethylene oxygen-permeable bags, or doubly packaged. For doublepackaging, aerobically packaged patties were repackaged in oxygen impermeable vacuum bags.

The packaged patties were irradiated at $2.5 \mathrm{kGy}$ using a Linear Accelerator (Circe IIIR, Thomson CSF Linac, France) with $10 \mathrm{MeV}$ of energy, $10 \mathrm{~kW}$ of power level, and $86.2 \mathrm{kGy} / \mathrm{min}$ of average dose rate. To confirm the target dose, two alanine dosimeters per cart were attached to the top and bottom surfaces of the sample and they were read using a 104 Electron Paramagnetic Resonance instrument (EMS-104, Bruker Instruments Inc., USA). Nonirradiated vacuum-packaged patties were prepared as

Table 1. Packaging, irradiation and antioxidant treatments used in this study

\begin{tabular}{cccccc}
\hline \hline \multirow{2}{*}{ Treatment } & Nonirradiated & \multicolumn{2}{c}{ Irradiated } \\
\cline { 2 - 6 } & Vacuum packaging & Vacuum packaging & Aerobic packaging & Double packaging & Double-S+E \\
\hline Antioxidant & & & & & None \\
Sesamol & None & None & None & None & $100 \mathrm{ppm}$ \\
$\alpha$-Tocopherol & None & None & None & $2.5 \mathrm{kGy}$ & $100 \mathrm{ppm}$ \\
Irradiation & $0 \mathrm{kGy}$ & $2.5 \mathrm{kGy}$ & $2.5 \mathrm{kGy}$ & & $2.5 \mathrm{kGy}$ \\
\hline Packaging & & & & & Vacuum \\
0 to $7 \mathrm{~d}$ & Vacuum & Vacuum & Aerobic & Aerobic & Aerobic \\
7 to $10 \mathrm{~d}$ & Vacuum & Vacuum & Aerobic & Aebum
\end{tabular}


a control. The outer vacuum bags of doubly packaged meat were removed after $7 \mathrm{~d}$ of storage at $4^{\circ} \mathrm{C}$ to expose the samples under aerobic conditions. Color, lipid oxidation and volatile compounds of the irradiated raw meats were determined at 0 and $10 \mathrm{~d}$ of refrigerated storage.

\section{Color measurement}

CIE color values were measured on the surface of sample using a LabScan color meter (Hunter Associated Labs. Inc., USA) that had been calibrated against a black and a white reference tiles covered with same packaging materials as used for samples. The CIE L* (lightness), a* (redness), and $\mathrm{b}^{*}$ (yellowness) values were obtained using an illuminant A (light source) with an area view of 0.25 " and a port size of $0.40 "$ "

\section{Analysis of 2-thiobarbituric acid reactive substan- ces (TBARS)}

Lipid oxidation was determined by a TBARS method (Ahn et al., 1998). Meat sample (5 g) was placed in a 50$\mathrm{mL}$ test tube and homogenized with $15 \mathrm{~mL}$ of deionized distilled water (DDW) using a Brinkman Polytron (Type PT 10/35, Brinkman Instrument Inc., USA) for $15 \mathrm{~s}$ at high speed. The meat homogenate $(1 \mathrm{~mL})$ was transferred to a disposable test tube $(13 \times 100 \mathrm{~mm})$, and butylated hydroxytoluene $(7.2 \%, 50 \mathrm{~mL})$ and thiobarbituric acid/trichloroacetic acid [20 mM TBA and 15\% (w/v) TCA] solution $(2 \mathrm{~mL})$ were added. The mixture was incubated in a $90^{\circ} \mathrm{C}$ water bath for $15 \mathrm{~min}$. After cooling for $10 \mathrm{~min}$ in cold water, the samples were centrifuged at $3,000 \mathrm{~g}$ for $15 \mathrm{~min}$ at $5^{\circ} \mathrm{C}$. The absorbance of the resulting upper layer was read at $531 \mathrm{~nm}$ against a blank prepared with $1 \mathrm{~mL}$ DDW and $2 \mathrm{~mL} \mathrm{TBA} / \mathrm{TCA}$ solution. The amounts of TBARS were expressed as mg of malonedialdehyde (MDA) per $\mathrm{kg}$ of meat.

\section{Oxidation-reduction potential (ORP)}

The method of Moiseev and Cornforth (1999) was modified to determine the change of ORP in meat samples. A pH/ion meter (Accumet 25, Fisher Scientific, USA) was used. A platinum electrode filled with a $4 \mathrm{M}-\mathrm{KCl}$ solution saturated with $\mathrm{AgCl}$ was tightly inserted in the center of a meat sample $(100 \mathrm{~g})$. To minimize the effect of air, the smallest possible pore was made by a cutter before inserting the electrode. To compensate for the effect of temperature, a temperature-reading sensor was also inserted. ORP readings $(\mathrm{mV})$ were recorded at exactly 3 min after the insertion of the electrode into the sample.

\section{Analysis of volatile profiles}

A purge-and-trap apparatus (Precept II and Purge \& Trap Concentrator 3000, Tekmar-Dohrmann, USA) connected to a gas chromatography/mass spectrometry (GC/MS, Hewlett-Packard Co., USA) was used to analyze volatiles produced (Ahn et al., 2000). Minced meat sample (3 g) was placed in a $40-\mathrm{mL}$ sample vial and the vials were flushed with $\mathrm{He}(40 \mathrm{psi})$ for $5 \mathrm{~s}$. Samples were held in a refrigerated $\left(4^{\circ} \mathrm{C}\right)$ sample-holding tray before analysis, and the maximum holding time was less than $7 \mathrm{~h}$ to minimize oxidative changes. The meat sample was purged with $\mathrm{He}$ (40 mL/min) for $13 \mathrm{~min}$ at $40^{\circ} \mathrm{C}$. Volatiles were trapped using a Tenax column (Tekmar-Dohrmann) and desorbed for $2 \mathrm{~min}$ at $225^{\circ} \mathrm{C}$, focused in a cryofocusing module ( -90 ${ }^{\circ} \mathrm{C}$ ), and then thermally desorbed into a column for $30 \mathrm{~s}$ at $225^{\circ} \mathrm{C}$. An HP-624 column (i.d. $7.5 \mathrm{~m} \times 0.25 \mathrm{~mm}$., 1.4 $\mu \mathrm{m}$ nominal), an HP-1 column $(52.5 \mathrm{~m} \times 0.25 \mathrm{~mm}$ i.d., $0.25 \mu \mathrm{m}$ nominal, Hewlett-Packard Co), and an HP-Wax column $(7.5 \mathrm{~m} \times 0.25 \mathrm{~mm}$., $0.25 \mu \mathrm{m}$ nominal $)$ were connected using zero dead-volume column connectors (J\&W Scientific, USA). Ramped oven temperature was used to improve volatile separation. The initial oven temperature of $0^{\circ} \mathrm{C}$ was held for $2.50 \mathrm{~min}$. After that, the oven temperature was increased to $15^{\circ} \mathrm{C}$ at $2.5^{\circ} \mathrm{C} / \mathrm{min}$, increased to $45^{\circ} \mathrm{C}$ at $5^{\circ} \mathrm{C} / \mathrm{min}$, increased to $110^{\circ} \mathrm{C}$ at $20^{\circ} \mathrm{C} / \mathrm{min}$, increased to $210^{\circ} \mathrm{C}$ at $10^{\circ} \mathrm{C} / \mathrm{min}$, and then was held for $4.5 \mathrm{~min}$ at the temperature. Constant column pressure at $20.5 \mathrm{psi}$ was maintained. The ionization potential of mass selective detector (Model 5973, Hewlett-Packard Co.) was 70 $\mathrm{eV}$, and the scan range was $18.1-300 \mathrm{~m} / \mathrm{z}$.

\section{Statistical analysis}

The experiment was designed to determine the effects of double-packaging and antioxidant combinations on color, lipid oxidation, and volatile profiles of the irradiated samples during storage. Analysis of variance was conducted by the generalized linear model procedure of SAS software (SAS Institute, 1995); Student-NewmanKeul's multiple range test was used to compare the mean values of the treatments. Mean values and standard error of the means (SEM) were reported at $p<0.05$ probability level.

\section{Results and Discussion}

\section{Color changes}

Packaging and irradiation had significant effects on all $L^{*}, a^{*}$ and $b^{*}$ values (Table 2). Irradiated restructured chicken rolls appeared lighter and redder than the nonirradi- 
Table 2. CIE color values of irradiated restructured chicken rolls treated by different packaging and antioxidant during the $10 \mathrm{~d}$ of storage

\begin{tabular}{|c|c|c|c|c|c|c|}
\hline \multirow{2}{*}{ Storage } & \multirow{2}{*}{$\begin{array}{c}\text { Nonirradiated }^{\prime} \\
\text { Vacuum packaging }\end{array}$} & \multicolumn{4}{|c|}{ Irradiated } & \multirow{2}{*}{ SEM } \\
\hline & & Vacuum packaging & Aerobic packaging & Double packaging $^{1}$ & Double-S+E ${ }^{2}$ & \\
\hline \multicolumn{7}{|l|}{$\mathrm{L}^{*}$ value } \\
\hline Day 0 & $47.6^{\mathrm{ey}}$ & $49.1^{\text {cdy }}$ & $53.8^{\mathrm{ax}}$ & $51.0^{\mathrm{b}}$ & $50.2^{\mathrm{bc}}$ & 0.4 \\
\hline Day 10 & $51.2^{\mathrm{abx}}$ & $51.8^{\mathrm{ax}}$ & $50.9^{\text {aby }}$ & $50.9^{\mathrm{ab}}$ & $49.8^{\mathrm{bc}}$ & 0.4 \\
\hline SEM & 0.5 & 0.4 & 0.5 & 0.4 & 0.4 & \\
\hline \multicolumn{7}{|l|}{ a* value } \\
\hline Day 0 & $5.4^{\mathrm{b}}$ & $7.5^{\mathrm{a}}$ & $5.9^{\mathrm{cx}}$ & $6.8^{\mathrm{bx}}$ & $6.7^{\mathrm{bx}}$ & 0.2 \\
\hline Day 10 & $5.6^{\mathrm{b}}$ & $7.4^{\mathrm{a}}$ & $3.1^{\text {cy }}$ & $5.9^{\text {by }}$ & $5.4^{\text {by }}$ & 0.1 \\
\hline SEM & 0.1 & 0.2 & 0.2 & 0.1 & 0.2 & \\
\hline \multicolumn{7}{|l|}{$\mathrm{b}^{*}$ value } \\
\hline Day 0 & $20.0^{\mathrm{ax}}$ & $19.1^{\mathrm{ax}}$ & $16.8^{\mathrm{bcx}}$ & $16.0^{\text {cy }}$ & $17.8^{\mathrm{b}}$ & 0.4 \\
\hline Day 10 & $18.9^{\text {ay }}$ & $17.9^{\text {by }}$ & $13.6^{\mathrm{cy}}$ & $17.7^{\mathrm{bx}}$ & $19.0^{\mathrm{a}}$ & 0.3 \\
\hline SEM & 0.2 & 0.3 & 0.4 & 0.2 & 0.4 & \\
\hline
\end{tabular}

${ }^{1}$ Vacuum-packaged for $7 \mathrm{~d}$ then aerobically packaged for $3 \mathrm{~d}$.

${ }^{2}$ Double packaging with sesamol (100 ppm) and a-tocopherol (100 ppm) added.

${ }^{\mathrm{a}-\mathrm{d}}$ Means with different letters within a row are significantly different $(p<0.05) ; \mathrm{n}=4$.

${ }^{x-z}$ Means with different letters within a column with same color value are significantly different $(p<0.05)$.

ated at $0 \mathrm{~d}(p<0.05)$. Many studies have shown that redness value of meats increased after irradiation (Du et al., 2002; Luchsinger et al., 1996). Du et al. (2003) indicated that gas production after irradiation could be responsible for the color changes in chicken rolls after irradiation. Many researchers (Lee and Ahn, 2004; Nam and Ahn., 2002) attributed the increased red color in irradiated meat to the formation of carbon monoxide-myoglobin (CO$\mathrm{Mb}$ ) complexes. The $\mathrm{CO}-\mathrm{Mb}$ complex is more stable than oxymyoglobin because of the strong binding of $\mathrm{CO}$ to the iron-porphyrin site on the myoglobin molecule (Sorheim et al., 1999).

The $\mathrm{a}^{*}$ value of aerobically packaged irradiated meat was lower than that of vacuum- and double-packaged irradiated one but still higher than the nonirraidated one at $0 \mathrm{~d}(p<0.05)$. These results also confirm the results of Nam and Ahn (2003) who reported that irradiation increased the $a^{*}$ value of raw turkey breast, but exposing the irradiated meat to aerobic conditions alleviated the intensity of redness. Nam et al. (2004) reported that the packaging conditions during irradiation process were important in determining meat color changes. Grant and Patterson (1991) also reported that irradiated color could be discolored in the presence of oxygen.

Vacuum-packaged and irradiated restructured chicken rolls had higher a* values and more stable red/pink color than the aerobic- and double-packaged irradiated one ( $p<$ 0.05). This is agreement with Nam and Ahn (2002) who found similar finding. Luchsinger et al. (1996) reported that irradiated vacuum-packaged pork chops appeared re- dder and were more stable during storage. The increased redness of vacuum-packaged samples by irradiation was stable even after $10 \mathrm{~d}$ of refrigerated storage. However, the redness of aerobic- or double-packaged and irradiated meats decreased significantly after $10 \mathrm{~d}$ of storage $(p<$ 0.05). This result agreed with that of Nam et al. (2003) who reported that regardless of irradiation, the color $\mathrm{a}^{*}$ values of meat decreased after $7 \mathrm{~d}$ of storage under aerobic conditions. Nam et al. (2003) indicated that heme pigments were oxidized during the storage period under aerobic conditions, and exposing irradiated meat to aerobic conditions was effective in reducing CO-heme pigment complex formation. Furthermore, the combination of antioxidants with double packaging showed a synergistic effect in reducing the redness of irradiated meat. The presence of oxygen could accelerate the dissociation of CO$\mathrm{Mb}$, whereas antioxidants could inhibit radiolytic generation of CO (Nam and Ahn, 2003).

Double packaging could lower $\mathrm{a}^{*}$ values of irradiated samples to the level of the nonirradiated control after 10 $\mathrm{d}$ of storage. From the result of packaging and antioxidant combinations, the $\mathrm{L}^{*}$ value of irradiated restructured chicken rolls from double packaging and antioxidant combinations $(\mathrm{G}+\mathrm{E})$ was lower than that of other treatments regardless of the storage period $(p<0.05)$. Irradiated restructured chicken rolls from double packaging and antioxidant combinations produced significantly lower $a^{*}$ values than the vacuum-packaged irradiated meats $(p<0.05)$. Adding a-tocopherol to sesamol or gallic acid did not increase a*values any further. Nam et al. (2003) reported 
that both irradiation and a-tocopherol increased a*values of turkey breast meat, but irradiation had a stronger impact. Antioxidants have been shown to improve color stability in irradiated fresh meats (Xiong et al., 1993). Some phenolic antioxidants (vitamin E) scavenge free-radicals stopping progressive autooxidative damage in meat (Gray et al., 1996; Morrissey et al., 1998). Therefore, the sesamol plus a-tocopherol in combination with double packaging can be effective in controlling off-color in irradiated meat.

\section{Lipid oxidation and oxidation-reduction potential}

Oxidative changes of irradiated restructured chicken rolls treated by different packaging and antioxidant during storage are shown in Table 3. Irradiation, antioxidants, and packaging methods influenced the TBARS values of irradiated restructured chicken rolls during storage. TBARS values of aerobic and double-packaged irradiated one increased during storage $(p<0.05)$ due to the oxygenimpermeable conditions during storage. Irradiation and storage time did not affect the TBARS values in vacuumpackaged samples. Previous studies have shown that irradiation promotes lipid oxidation and generates characteristic off-odor volatiles in meats (Nam and Ahn, 2003). Irradiation produced more TBARS than nonirradiated samples, but only in aerobic-packaged samples at $10 \mathrm{~d}$ ( $p<$ 0.05 ). Previous studies indicated that irradiated aerobicpackaged meat produced higher TBARS and off-flavor than the irradiated vacuum-packaged and nonirradiated ones (Ahn et al., 2001; Du et al., 2002; Patterson and Stevenson, 1995). As storage time increased, lipid oxidation in irradiated meats increased significantly. This result agreed with Nam et al. (2003) who reported similar result. The TBARS of meat was highest with aerobic packaging, lowest with double packaging and antioxidant combinations, and in the middle with double packaging $(p<0.05)$.
The effects of double packaging and antioxidant combinations were distinct after $10 \mathrm{~d}$ of storage in inhibiting lipid oxidation. The TBARS of antioxidant-treated double packaging meats were lower than even nonirradiated vacuum-packaging meat at $10 \mathrm{~d}(p<0.05)$.

The TBARS values increased sharply (five to six-fold) in aerobic packaging during storage. It could be affected by the fact that it is susceptible to oxidative changes. This result agreed with our previous work (Jo et al., 1999) and could be interpreted as showing that storage condition or oxygen availability was more important for the development of lipid oxidation than irradiation (Ahn et al., 1998). Vacuum-packaged meat was more resistant to lipid oxidation than aerobically packaged meat. In a previous study, Nam and Ahn (2003a) found that the TBARS increase could be proportional to the exposure time to aerobic conditions. Irradiation did not increase the TBARS under vacuum packaging regardless of the storage period. With vacuum packaging, no difference in TBARS was found regardless of irradiation and storage. The added antioxidant effect to reduce TBARS was found in irradiated restructured chicken rolls. Double-packaged irradiated one added by sesamol plus a-tocopherol was significantly lower than other treatments $(p<0.05)$. Double-packaged irradiated samples added by antioxidants showed the lowest TBARS value on 0 and $10 \mathrm{~d}(p<0.05)$. This finding agreed with Nam et al. (2007) who found that the irradiated meat with antioxidants and double packaging combinations had lower TBARS than nonirradiated vacuum-packaged meat after $10 \mathrm{~d}$ of storage. The combination of sesamol plus g-tocopherol was efficient in inhibiting hydroperoxide formation in oils (Yoshida and Takagi, 1999). Therefore, antioxidant combination was very effective in preventing lipid oxidation during storage, and the TBARS of antioxidant-treated meats were lower than even nonirradiated vacuum-packaged meat at $10 \mathrm{~d}$. Nam et al. (2003)

Table 3. TBARS values of irradiated restructured chicken rolls treated by different packaging and antioxidant during the $10 \mathrm{~d}$ of storage

\begin{tabular}{|c|c|c|c|c|c|c|}
\hline \multirow{2}{*}{ Storage } & \multirow{2}{*}{$\begin{array}{c}\text { Nonirradiated } \\
\text { Vacuum packaging }\end{array}$} & \multicolumn{4}{|c|}{ Irradiated } & \multirow{2}{*}{ SEM } \\
\hline & & Vacuum packaging & Aerobic packaging & Double packaging $^{1}$ & Double-S+E ${ }^{2}$ & \\
\hline & \multicolumn{6}{|c|}{ 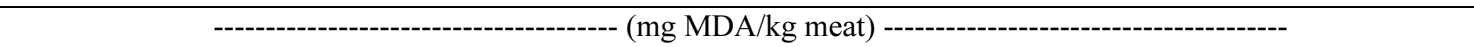 } \\
\hline Day 0 & $0.57^{b}$ & $0.61^{\mathrm{b}}$ & $0.89^{\text {ay }}$ & $0.64^{\text {by }}$ & $0.24^{\mathrm{cy}}$ & 0.02 \\
\hline Day 10 & $0.60^{\mathrm{cd}}$ & $0.68^{c}$ & $5.19^{\mathrm{ax}}$ & $1.79^{\mathrm{bx}}$ & $0.32^{\mathrm{dx}}$ & 0.07 \\
\hline SEM & 0.01 & 0.02 & 0.08 & 0.08 & 0.01 & \\
\hline
\end{tabular}

${ }^{1}$ Vacuum-packaged for $7 \mathrm{~d}$ then aerobically packaged for $3 \mathrm{~d}$.

${ }^{2}$ Double packaging with sesamol (100 ppm) and a-tocopherol (100 ppm) added.

${ }^{\text {a-d }}$ Means with different letters within a row are significantly different $(p<0.05) ; \mathrm{n}=4$.

${ }^{\mathrm{x}-\mathrm{z}}$ Means with different letters within a column with same color value are significantly different $(p<0.05)$. 
showed that irradiated restructured pork loins treated with antioxidant and double-packaging had lower TBARS values than vacuum-packaged control after $10 \mathrm{~d}$ of storage. Ahn et al. (1997) reported that antioxidant reduces oxidative quality deterioration of irradiated meat by quenching free radicals. Nam and Ahn (2003) showed that gallate or sesamol combined with a-tocopherol decreased the production of sulfur volatiles as well as lipid oxidation in irradiated pork patties. Chen et al. (1999) also indicated that phenolic antioxidants were effective in reducing lipid oxidation in aerobically packaged irradiated pork patties.

To elucidate the change of oxidative status of the heme pigments of irradiated restructured chicken rolls, ORP values were determined (Table 4). Regardless of the packaging methods, irradiation initially lowered ORP values on $0 \mathrm{~d}$. After $10 \mathrm{~d}$ of storage, the differences of ORP between nonirradiated and irradiated samples reversed. While nonirradiated samples under vacuum packaging had higher ORP than irradiated ones on day 0 , those had lower on 10 $\mathrm{d}(p<0.05)$. In Irradiated samples, vacuum-packaged ones had much lower ORP values than the aerobic-packaged ones $(p<0.05)$. Nam and Ahn (2002) also mentioned that the iron of myoglobin was changed to a ferrous iron under the reduced conditions of irradiated turkey breast, and the reduced iron had stronger affinity to accept a ligand and produced a red color.

As the storage time increased, ORP values in irradiated meat increased, whereas the ORP in nonirradiated samples decreased in vacuum packaging conditions. This result is very similar to Nam and Ahn (2002) and Ismail et al. (2008). Du et al. (2002), reporting similar results with chicken breast meat, hypothesized that the decrease in ORP could be due to the electrons absorbed during irradiation. And they suggested that the ORP changes seen in aerobically packaged fillets may be due to irradiationinduced membrane damage, which increases oxygen per- meability into the tissues. Nam and Ahn (2002) also reported an immediate decrease in ORP due to irradiation followed by an increase during storage that was greater in aerobically-packaged than in vacuum-packaged meat. Generally, the ORP of raw meats declined during storage due to the oxygen consumption by meat tissues or microorganisms (Ismail et al., 2008). Cornforth et al. (1986) elucidated that microbial growth decreased ORP and thus increased reducing capacity. Although ORP value decreased in the processing of irradiation, the reduced condition produced in irradiated meat was not maintained during the storage. The result did not coincide with the red color of stored irradiated meat, because the color of irradiated meats was still redder or pinker than nonirradiated meats during storage. The TBARS values of meat samples were related to ORP and packaging type. Vacuum-packaged samples had lower ORP and TBARS values than aerobically packaged Samples. Therefore, the result of the study showed that use of double-packaging and antioxidant combinations reduced lipid oxidation for all irradiated treatments as the storage period increased.

\section{Off-odor volatiles}

Irradiated meats produced more total volatiles than nonirradiated ones with vacuum packaging at $0 \mathrm{~d}(p<0.05)$ (Table 5). Many studies have shown that irradiation induced production of several off-odor volatiles compounds (Ahn et al., 2001, Kim et al., 2002). Nam et al. (2003) indicated that irradiation of restructured pork loins increased the amount of total volatiles by about $25 \%$. Ahn et $a l$. (2000) indicated that the major contributor of off-odor in irradiated meat is not lipid oxidation, but radiolytic breakdown of sulfur-containing amino acids.

The most distinctive changes in volatile profiles by irradiation were the increase of sulfur volatiles (methanethiol, dimethyl disulfide), aldehydes (2-methylbutanal, pentanal,

Table 4. ORP values of irradiated restructured chicken rolls treated by different packaging and antioxidant during the $10 \mathrm{~d}$ of storage

\begin{tabular}{|c|c|c|c|c|c|c|}
\hline \multirow{2}{*}{ Storage } & \multirow{2}{*}{$\begin{array}{c}\text { Nonirradiated } \\
\text { Vacuum packaging }\end{array}$} & \multicolumn{4}{|c|}{ Irradiated } & \multirow{2}{*}{ SEM } \\
\hline & & Vacuum packaging & Aerobic packaging & Double packaging $^{1}$ & Double-S $+\mathrm{E}^{2}$ & \\
\hline & \multicolumn{6}{|c|}{------------------------------------------------- $(\mathrm{mV})$----------------------------------------------- } \\
\hline Day 0 & $-2.5^{\mathrm{ax}}$ & $-95.5^{\mathrm{c}}$ & $-65.4^{\text {by }}$ & $-141.2^{\mathrm{dy}}$ & $-125.2^{\text {cdy }}$ & 9.1 \\
\hline Day 10 & $-82.7^{\mathrm{cy}}$ & $-67.9^{b}$ & $-42.5^{\mathrm{ax}}$ & $-50.3^{a x}$ & $-48.5^{a x}$ & 5.2 \\
\hline SEM & 5.1 & 9.8 & 4.1 & 10.0 & 5.8 & \\
\hline
\end{tabular}

${ }^{1}$ Vacuum-packaged for $7 \mathrm{~d}$ then aerobically packaged for $3 \mathrm{~d}$.

${ }^{2}$ Double packaging with sesamol (100 ppm) and a-tocopherol (100 ppm) added.

${ }^{\mathrm{a}-\mathrm{d}}$ Means with different letters within a row are significantly different $(p<0.05) ; \mathrm{n}=4$.

${ }^{\mathrm{x}-\mathrm{z}}$ Means with different letters within a column with same color value are significantly different $(p<0.05)$. 
Table 5. Volatile profiles of irradiated restructured chicken rolls treated by different packaging and antioxidant at $0 \mathrm{~d}$

\begin{tabular}{|c|c|c|c|c|c|c|}
\hline \multirow{2}{*}{ Compound } & \multirow{2}{*}{$\frac{\text { Nonirradiated }}{\text { Vacuum }}$} & \multicolumn{4}{|c|}{ Irradiated } & \multirow{2}{*}{ SEM } \\
\hline & & Vacuum & Aerobic & Double $^{1}$ & Double-S+E ${ }^{2}$ & \\
\hline & \multicolumn{6}{|c|}{ 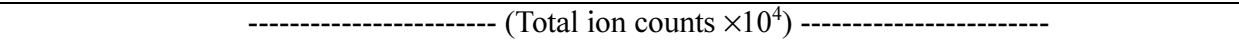 } \\
\hline 2-Methyl-1-Propene & $0^{\mathrm{c}}$ & $432^{\mathrm{b}}$ & $531^{\mathrm{b}}$ & $447^{\mathrm{b}}$ & $547^{\mathrm{b}}$ & 50 \\
\hline Butane & $452^{\mathrm{c}}$ & $837^{\mathrm{b}}$ & $1221^{\mathrm{a}}$ & $1351^{\mathrm{a}}$ & $1197^{\mathrm{a}}$ & 93 \\
\hline 1-Butene & $0^{\mathrm{b}}$ & $287^{\mathrm{a}}$ & $341^{\mathrm{a}}$ & $365^{\mathrm{a}}$ & $390^{\mathrm{a}}$ & 44 \\
\hline Methanethiol & 0 & 153 & 0 & 0 & 0 & 36 \\
\hline 1-Pentene & $0^{\mathrm{b}}$ & $313^{\mathrm{a}}$ & $420^{\mathrm{a}}$ & $277^{\mathrm{a}}$ & $282^{\mathrm{a}}$ & 34 \\
\hline Pentane & $4397^{b}$ & $8654^{\mathrm{a}}$ & $8510^{\mathrm{a}}$ & $10188^{\mathrm{a}}$ & $2988^{b}$ & 745 \\
\hline Dimethyl sulfide & $282^{\mathrm{b}}$ & $461^{\mathrm{a}}$ & $0 \mathrm{c}$ & $389^{\mathrm{ab}}$ & $507^{\mathrm{a}}$ & 43 \\
\hline Carbon disulfide & $2863^{\mathrm{a}}$ & $2962^{\mathrm{a}}$ & $1451^{\mathrm{b}}$ & $2587^{\mathrm{a}}$ & $506^{\mathrm{b}}$ & 383 \\
\hline 1-Hexene & $0^{\mathrm{b}}$ & $233^{\mathrm{a}}$ & $264^{\mathrm{a}}$ & $203^{\mathrm{a}}$ & $204^{\mathrm{a}}$ & 20 \\
\hline Hexane & $815^{\mathrm{b}}$ & $995^{\mathrm{b}}$ & $7606^{\mathrm{a}}$ & $922^{\mathrm{b}}$ & $632^{\mathrm{b}}$ & 112 \\
\hline Benzene & $0^{\mathrm{c}}$ & $706^{\mathrm{a}}$ & $516^{\mathrm{b}}$ & $712^{\mathrm{a}}$ & $497^{\mathrm{b}}$ & 46 \\
\hline 3-Methyl butanal & $0^{\mathrm{d}}$ & $44^{\mathrm{b}}$ & $405^{\mathrm{a}}$ & $0^{\mathrm{b}}$ & $0^{\mathrm{b}}$ & 26 \\
\hline 1-Heptene & $0^{\mathrm{d}}$ & $453^{\mathrm{c}}$ & $762^{\mathrm{a}}$ & $410^{\mathrm{c}}$ & $366^{\mathrm{c}}$ & 40 \\
\hline Heptane & $972^{b c}$ & $1158^{\mathrm{bc}}$ & $2504^{\mathrm{a}}$ & $1100^{\mathrm{bc}}$ & $613^{\mathrm{c}}$ & 142 \\
\hline Pentanal & $0^{\mathrm{b}}$ & $40^{\mathrm{b}}$ & $304^{\mathrm{a}}$ & $0^{\mathrm{b}}$ & $0^{\mathrm{b}}$ & 27 \\
\hline 2,3,4-Trimethyl pentane & $0^{\mathrm{b}}$ & $122^{\mathrm{a}}$ & $0^{\mathrm{b}}$ & $0^{\mathrm{b}}$ & $0^{\mathrm{b}}$ & 3 \\
\hline 2.3.3-Trimethyl pentane & $0^{\mathrm{b}}$ & $129^{\mathrm{a}}$ & $0^{\mathrm{b}}$ & $0^{\mathrm{b}}$ & $0^{\mathrm{b}}$ & 23 \\
\hline Dimethyl disulfide & $0^{\mathrm{c}}$ & $807^{\mathrm{a}}$ & $217^{\mathrm{bc}}$ & $708^{\mathrm{ab}}$ & $489^{\mathrm{ab}}$ & 132 \\
\hline Toluene & $231^{\mathrm{c}}$ & $871^{\mathrm{b}}$ & $904^{\mathrm{b}}$ & $844^{\mathrm{b}}$ & $975^{a b}$ & 69 \\
\hline 4-Octene & 410 & 789 & 317 & 461 & 431 & 110 \\
\hline Octane & $893^{\mathrm{c}}$ & $2094^{a}$ & $2060^{\mathrm{a}}$ & $2285^{\mathrm{a}}$ & $1263^{\mathrm{b}}$ & 115 \\
\hline 2-Octene & $190^{\mathrm{b}}$ & $421^{\mathrm{a}}$ & $135^{\mathrm{b}}$ & $256^{\mathrm{b}}$ & $221^{\mathrm{b}}$ & 47 \\
\hline 3-Methyl-2-heptene & $373^{\mathrm{b}}$ & $613^{\mathrm{a}}$ & $0^{\mathrm{b}}$ & $250^{\mathrm{b}}$ & $218^{\mathrm{b}}$ & 102 \\
\hline 2-Octene & 158 & 298 & 141 & 186 & 223 & 44 \\
\hline Hexanal & $0^{\mathrm{b}}$ & $42^{\mathrm{b}}$ & $685^{\mathrm{a}}$ & $0^{\mathrm{b}}$ & $0^{\mathrm{b}}$ & 95 \\
\hline Nonane & $0^{\mathrm{b}}$ & $39^{\mathrm{b}}$ & $176^{\mathrm{a}}$ & $79^{\mathrm{ab}}$ & $60^{\mathrm{ab}}$ & 29 \\
\hline Total & $7187^{d}$ & $23960^{\mathrm{ab}}$ & $29567^{\mathrm{a}}$ & $24027^{\mathrm{ab}}$ & $12599^{\mathrm{c}}$ & 1584 \\
\hline
\end{tabular}

${ }^{1}$ Vacuum-packaged for $7 \mathrm{~d}$ then aerobically packaged for $3 \mathrm{~d}$.

${ }^{2}$ Double packaging with sesamol (100 ppm) and a-tocopherol (100 ppm) added.

${ }^{\mathrm{a}-\mathrm{d}}$ Different letters within a row are significantly different $(p<0.05) ; \mathrm{n}=4$.

and hexanal) and 1-alkenes (1-pentene, 1-hexene, 1-hepene, 1-octene), which were newly generated (Table 5). The major sulfur volatiles produced in samples by irradiation were methanethiol and dimethyl disulfide. Dimethyl disulfide is usually found in irradiated raw and cooked meat and usually evaporates during storage (Ahn et al., 2001). Dimethyl disulfide and other sulfur compounds were derived from degradation of amino acids and were suggested to be the major volatile compounds imparting irradiation off-odor (Ahn et al., 2000). In our study, dimethyl disulfide was not detected in nonirradiated meat at 0 and $10 \mathrm{~d}$ in vacuum conditions. Dimethyl disulfide decreased during storage regardless of packaging conditions, and aerobically packaged irradiated meat had only one-fourth the dimethyl disulfide of the vacuum-packaged meat ( $p<$ 0.05). This is consistent with results from Brewer (2004) who indicated that irradiation produced significant amou- nts of sulfur volatiles under vacuum conditions and these compounds disappeared after storage in aerobic conditions.

S-containing volatiles, such as dimethyl disulfide produced by radiolytic degradation of sulfur amino acids, are responsible for the off-odor in irradiated meat, and are different from the rancidity caused by lipid oxidation products (Ahn et al., 2001). The lower levels of sulfur compounds in aerobically packaged samples might be due to the fact that the aerobically packaged meat had weaker irradiation odor than that of the vacuum-packaged (Du et al., 2002). Most of the sulfur volatiles in irradiated turkey breast disappeared under aerobic packaging conditions (Nam and Ahn, 2003). The amount of hexanal in irradiated samples under aerobic packaging condition was detected or higher than that of other samples $(p<0.05)$. Hexanal was the major volatile aldehydes and the increase of aldehydes agreed well with TBARS data. Hexa- 
nal and pentanal are a good indicator of lipid oxidation (Shahidi et al., 1987) and hexanal is an off-flavor volatile typically associated with oxidative changes (Ahn et al., 2001).

When irradiated beef was aerobically stored, the generation of lipid oxidation products was a bigger concern than S-volatiles, because aerobic packaging is very effective in eliminating S-volatiles (Nam et al., 2003). Nam and Ahn. (2003) mentioned that double packaging could minimize irradiation off-odor by volatilizing S-volatile compounds in irradiated poultry meat. Double packaging and antioxidant combinations lowered total volatiles in meat, and methanethiol, pentanal, trimethyl pentane and hexanal were not detected $(p<0.05)$. In a previous study, double-packaging was effective in minimizing lipid oxidation, pink color defect and sulfur-volatile production in irradiated pork loin during storage (Nam et al., 2004), but combination of double-packaging and antioxidants was more effective than double-packaging alone in controlling lipid oxidation and irradiation off-odor (Nam and Ahn, 2003). In a previous study, antioxidants such as gallate, tocopherol, and sesamol were effective in reducing the off-odor volatiles produced by irradiation, but sesamol was the most effective among them. Sesamol plus tocopherol

Table 6. Volatile profiles of irradiated restructured chicken rolls treated by different packaging and antioxidant after $10 \mathrm{~d}$ of refrigerated storage

\begin{tabular}{|c|c|c|c|c|c|c|}
\hline \multirow{2}{*}{ Compound } & \multirow{2}{*}{$\begin{array}{c}\text { Nonirradiated } \\
\text { Vacuum }\end{array}$} & \multicolumn{4}{|c|}{ Irradiated } & \multirow{2}{*}{ SEM } \\
\hline & & Vacuum & Aerobic & Double $^{1}$ & Double-S+E ${ }^{2}$ & \\
\hline & \multicolumn{6}{|c|}{ 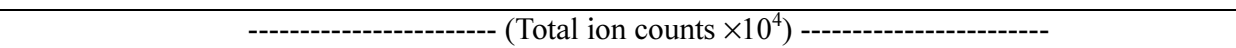 } \\
\hline 2-Methyl-1-Propene & $0^{\mathrm{c}}$ & $598^{\mathrm{a}}$ & $0^{\mathrm{c}}$ & $279^{b}$ & $402^{\mathrm{ab}}$ & 58 \\
\hline Butane & $1248^{\mathrm{b}}$ & $1381^{\mathrm{b}}$ & $4065^{\mathrm{a}}$ & $1212^{\mathrm{b}}$ & $925^{\mathrm{b}}$ & 93 \\
\hline 1-Butene & $0^{\mathrm{b}}$ & $380^{\mathrm{a}}$ & $0^{\mathrm{b}}$ & $0^{\mathrm{b}}$ & $0^{\mathrm{b}}$ & 20 \\
\hline 1-Pentene & $0^{\mathrm{d}}$ & $373^{b}$ & $500^{\mathrm{a}}$ & $244^{\mathrm{c}}$ & $215^{\mathrm{c}}$ & 30 \\
\hline Pentane & $14874^{\mathrm{c}}$ & $16645^{\mathrm{c}}$ & $40980^{a}$ & $20218^{\mathrm{bc}}$ & $6025^{\mathrm{d}}$ & 1624 \\
\hline Ethanol & $1971^{\mathrm{a}}$ & $0^{\mathrm{b}}$ & $0^{\mathrm{b}}$ & $0^{\mathrm{b}}$ & $0^{\mathrm{b}}$ & 87 \\
\hline 2-Pentene & $0^{\mathrm{b}}$ & $0^{\mathrm{b}}$ & $322^{\mathrm{a}}$ & $0^{\mathrm{b}}$ & $0^{\mathrm{b}}$ & 10 \\
\hline Propanal & $0^{\mathrm{b}}$ & $0^{\mathrm{b}}$ & $133^{\mathrm{a}}$ & $0^{\mathrm{b}}$ & $0^{\mathrm{b}}$ & 31 \\
\hline Dimethyl sulfide & $425^{b}$ & $504^{\mathrm{a}}$ & $0^{\mathrm{d}}$ & $0^{\mathrm{d}}$ & $216^{\mathrm{c}}$ & 18 \\
\hline Carbon disulfide & $2539^{\mathrm{a}}$ & $2520^{\mathrm{a}}$ & $0^{\mathrm{b}}$ & $42^{b}$ & $0^{\mathrm{b}}$ & 1326 \\
\hline 2-Methyl propanal & 0 & 0 & 133 & 0 & 0 & 31 \\
\hline 1-Hexene & $0^{\mathrm{c}}$ & $292^{\mathrm{a}}$ & $348^{\mathrm{a}}$ & $167^{\mathrm{b}}$ & $163^{b}$ & 22 \\
\hline Hexane & $1387^{\mathrm{c}}$ & $2090^{\mathrm{b}}$ & $4979^{\mathrm{a}}$ & $1781^{\mathrm{bc}}$ & $888^{d}$ & 260 \\
\hline Benzene & $0^{\mathrm{d}}$ & $928^{a}$ & $336^{\mathrm{c}}$ & $431^{\mathrm{bc}}$ & $373^{c}$ & 46 \\
\hline 3-Methyl butanal & $184^{\mathrm{b}}$ & $0^{\mathrm{b}}$ & $897^{\mathrm{a}}$ & $0^{\mathrm{b}}$ & $0^{\mathrm{b}}$ & 166 \\
\hline 2-Methyl butanal & $477^{\mathrm{b}}$ & $0^{\mathrm{c}}$ & $1450^{\mathrm{a}}$ & $0^{\mathrm{c}}$ & $0^{\mathrm{c}}$ & 22 \\
\hline 1-Heptene & $0^{\mathrm{c}}$ & $519^{a}$ & $0 \mathrm{c}$ & $400^{\mathrm{ab}}$ & $292^{b}$ & 54 \\
\hline Heptane & $2262^{\mathrm{c}}$ & $3625^{\mathrm{b}}$ & $9059^{a}$ & $2957^{\mathrm{bc}}$ & $991^{\mathrm{d}}$ & 491 \\
\hline 2-Ethyl furan & $0^{\mathrm{b}}$ & $0^{\mathrm{b}}$ & $228^{a}$ & $0^{\mathrm{b}}$ & $0^{\mathrm{b}}$ & 7 \\
\hline Pentanal & $0^{\mathrm{b}}$ & $0^{\mathrm{b}}$ & $2891^{\mathrm{a}}$ & $0^{\mathrm{b}}$ & $0^{\mathrm{b}}$ & 177 \\
\hline 2,3,4-Trimethyl pentane & $25^{b}$ & $164^{\mathrm{a}}$ & $0^{\mathrm{b}}$ & $0^{\mathrm{b}}$ & $0^{\mathrm{b}}$ & 74 \\
\hline 2.3.3-Trimethyl pentane & $50^{\mathrm{b}}$ & $175^{\mathrm{a}}$ & $0^{\mathrm{b}}$ & $0^{\mathrm{b}}$ & $0^{\mathrm{b}}$ & 82 \\
\hline Dimethyl disulfide & $0^{c}$ & $251^{\mathrm{a}}$ & $125^{b}$ & $0^{\mathrm{c}}$ & $0^{\mathrm{c}}$ & 28 \\
\hline Toluene & $305^{\mathrm{b}}$ & $965^{\mathrm{a}}$ & $607^{b}$ & $508^{b}$ & $481^{\mathrm{b}}$ & 91 \\
\hline 4-Octene & $204^{b}$ & $0^{\mathrm{c}}$ & $521^{\mathrm{a}}$ & $290^{\mathrm{b}}$ & $0^{\mathrm{c}}$ & 44 \\
\hline Octane & $3090^{\mathrm{bc}}$ & $5625^{\mathrm{ab}}$ & $7432^{\mathrm{a}}$ & $3456^{\mathrm{bc}}$ & $1462^{\mathrm{c}}$ & 977 \\
\hline 2-Octene & $525^{\mathrm{a}}$ & $662^{a}$ & $832^{a}$ & $230^{\mathrm{b}}$ & $194^{b}$ & 201 \\
\hline 3-Methyl-2-heptene & 82 & 677 & 78 & 100 & 184 & 370 \\
\hline 2-Octene & 164 & 390 & 437 & 166 & 154 & 182 \\
\hline Hexanal & $79^{\mathrm{b}}$ & $0^{\mathrm{b}}$ & $30296^{a}$ & $30^{b}$ & $0^{\mathrm{b}}$ & 1307 \\
\hline Nonane & $0^{\mathrm{b}}$ & $142^{\mathrm{ab}}$ & $224^{\mathrm{a}}$ & $108^{\mathrm{ab}}$ & $0^{\mathrm{b}}$ & 39 \\
\hline Total & $29897^{b}$ & $38912^{b}$ & $107576^{\mathrm{a}}$ & $32626^{b}$ & $12970^{\mathrm{c}}$ & 3170 \\
\hline
\end{tabular}

${ }^{1}$ Vacuum-packaged for $7 \mathrm{~d}$ then aerobically packaged for $3 \mathrm{~d}$.

${ }^{2}$ Double packaging with sesamol (100 ppm) and a-tocopherol (100 ppm) added.

${ }^{\mathrm{a}-\mathrm{d}}$ Different letters within a row are significantly different $(p<0.05) ; \mathrm{n}=4$. 
was the most effective in reducing carbon disulfide, 3methylbutanal, and total volatiles production (Nam and Ahn, 2003).

The beneficial effects of double packaging and antioxidant combinations on volatiles were more apparent in irradiated after $10 \mathrm{~d}$ of refrigerated storage (Table 6). Volatile profiles of irradiated samples were highly dependent upon antioxidant and packaging conditions. Aerobicpackaged irradiated ones had the greatest amounts of total volatiles. The amount of dimethyl disulfide decreased two-four fold compared with that at $0 \mathrm{~d}(p<0.05)$, and these sulfur volatiles were not detected in irradiated double packaging and antioxidant combinations group. The result at $10 \mathrm{~d}$ was similar to Nam et al. (2003) who reported most sulfur volatiles reduced regardless of packaging conditions, after $10 \mathrm{~d}$ of storage. Three days of exposure to aerobic conditions was enough for the sulfur volatiles to escape from the meat (Nam and Ahn, 2003). However, aerobically packaged irradiated meat without antioxidants produced large amounts of aldehydes (propanal, hexanal) and 2-methyl butanone at $10 \mathrm{~d}$. Doublepackaged meat had lower lipid oxidation products compared with aerobically packaged meat, but antioxidant combinations significantly reduced the amount of pentane at $10 \mathrm{~d}$. Therefore, the combination of double packaging (vacuum for $3 \mathrm{~d}$ then aerobic for 7) with antioxidants in irradiated samples was very effective in reducing total and sulfur volatiles responsible for the irradiation off-odor without any problem in lipid oxidation. In conclusion, the combination of double packaging and antioxidants was highly effective in controlling lipid oxidation and irradiation off-odor of irradiated restructured chicken rolls.

\section{Acknowledgements}

This work was supported from Radiation Technology R\&D program (2013M2A2A6043308) through the National Research Foundation of Korea funded by the Ministry of Science, ICT \& Future Planning.

\section{References}

1. Ahn, D. U., Jo, C., and Olson, D. G. (2000) Analysis of volatile components and the sensory characteristics of irradiated raw pork. Meat Sci. 54, 209-215.

2. Ahn, D. U., Nam, K. C., Du, M., and Jo, C. (2001) Volatile production in irradiated normal, pale soft exudative (PSE) and dark firm dry (DFD) pork under different packaging and storage conditions. Meat Sci. 57, 419- 426.

3. Ahn, D. U., Olson, D. G., Jo, C., Chen, X., Wu, C., and Lee,
J. I. (1998) Effect of muscle type, packaging, and irradiation on lipid oxidation, volatile production, and color in raw pork patties. Meat Sci. 47, 27-39.

4. Brewer, S. (2004) Irradiation effects on meat color-A review. Meat Sci. 68, 1-17.

5. Chen, X. and Ahn, D. U. (1998) Antioxidant activities of six natural phenolics against lipid oxidation induced by $\mathrm{Fe}^{2+}$ or ultraviolet light. J. Am. Oil Chem. Soc. 75, 1717-1721.

6. Chen, X., Jo, C., Lee, J. I., and Ahn, D. U. (1999) Lipid oxidation, volatiles, and color changes of irradiated pork patties as affected by antioxidants. J. Food Sci. 64, 16-19.

7. Cornforth, D. P., Vahabzadeh, F., Carpenter, C. E., and Bartholomew, D. T. (1986) Role of reduced hemochromes in pink color defect of cooked turkey rolls. J. Food Sci. 51, 11321135.

8. Du, M., Hur, S. J. L., and Ahn, D. U. (2002) Raw-meat packaging and storage affect the color and odor of irradiated broiler breast fillets after cooking. Meat Sci. 61, 49-54.

9. Du, M., Nam, K. C., Hur, S. J., Ismail, H., Kim, Y. H., and Ahn, D. U. (2003) Quality characteristics of irradiated chicken breast rolls from broilers fed different levels of conjugated linoleic acid. Meat Sci. 63, 249-255.

10. Gants, R. (1998) Irradiation: weighing the risks and benefits. Meat and Poultry. April, pp. 34-42.

11. Grant, I. R. and Patterson, M. F. (1991) Effect of irradiation and modified atmosphere packaging on the microbiological and sensory quality of pork stored at refrigeration temperatures. Int. J. Food Sci. Technol. 26, 507-519.

12. Gray, J. I., Gomaa, E. A., and Buckley, D. J. (1996) Oxidative quality and shelf life of meats. Meat Sci. 43, 111-123.

13. Ismail, H. A., Lee, E. J., Ko, K. Y., and Ahn, D. U. (2008) Effects of aging time and natural antioxidants on the color, lipid oxidation and volatiles of irradiated ground beef. Meat Sci. 80, 582-591

14. Jo, C., Lee, J. I., and Ahn, D. U. (1999) Lipid oxidation, color, and volatile changes in irradiated pork sausages with different fat content and packaging during storage. Meat Sci. 51, 355-361.

15. Katusin-Razem, B., Mihaljevic, K. W., and Razem, D. (1992) Time-dependent post irradiation oxidative chemical changes in dehydrated egg products. J. Agr. Food Chem. 40, 19481952.

16. Kim, Y. H., Nam, K. C., and Ahn, D. U. (2002) Volatile profiles, lipid oxidation and sensory characteristics of irradiated meat from different animal species. Meat Sci. 61, 257-265.

17. Lambert, A. D., Smith, J. P., and Dodds, K. L. (1991) Shelf life extension and microbiological safety of fresh meat: A review. Food Microbiol. 8, 267-297.

18. Lee, E. J. and Ahn, D. U. (2004) Sources and mechanisms of carbon monoxide production by irradiation. J. Food Sci. 69, 485-490.

19. Luchsinger, S. E., Kropf, D. H., Garcia-Zepeda, C. M., Hunt, M. C., Marsden, J. L., Rubio-Canas, E. J., Kastner, C. L., Kuecher, W. G., and Mata, T. (1996) Color and oxidative rancidity of gamma and electron beam-irradiated boneless pork chops. J. Food Sci. 61, 1000-1005. 
20. Lynch, J. A., MacFie, H. J. H., and Mead, G. C. (1991) Effect of irradiation and packaging type on sensory quality of chilledstored turkey breast fillets. Int. J. Food Sci. Technol. 26, 653668.

21. Moiseev, I. V. and Cornforth, D. P. (1999) Treatments for prevention of persistent pinking in dark-cutting beef patties. $J$. Food Sci. 64, 738-743.

22. Molins, R. A., Motarjemi, Y., and Kaferstein, F. K. (2001) Irradiation: A critical control point in ensuring the microbiological safety of raw foods. Food Control 12, 347-356.

23. Morrissey, P. A., Sheehy, P. J. A., Galvin, K., Kerry, J. P., and Buckley, D. J. (1998) Lipid stability in meat and meat products. Meat Sci. 49, 73-86.

24. Nam, K. C. and Ahn, D. U. (2002) Carbon monoxide-heme pigment is responsible for the pink color in irradiated raw turkey breast meat. Meat Sci. 60, 25-33.

25. Nam, K. C. and Ahn, D. U. (2003) Combination of aerobic and vacuum packaging to control lipid oxidation and off-odor volatiles of irradiated raw turkey breast. Meat Sci. 63, 389395.

26. Nam, K. C., Ko, K. Y., Min, B. R., Ismail, H., Lee, E. J., Cordray, J., and Ahn, D. U. (2007) Effects of oleoresin-tocopherol combinations on lipid oxidation, off-odor, and color of irradiated raw and cooked pork patties. Meat Sci. 75, 61-70.

27. Nam, K. C., Min, B. R., Lee, S. C., Cordray, J., and Ahn, D. U. (2004) Prevention of pinking, off-odor, and lipid oxidation in irradiated pork loin using double packaging. J. Food Sci. 69, 214-219.
28. Nam, K. C., Min, B. R., Yan, H., Lee, E. J., Mendonca, A., Wesley, I., and Ahn, D. U. (2003) Effect of dietary vitamin E and irradiation on lipid oxidation, color and volatiles of fresh and previously frozen turkey breast patties. Meat Sci. 65, 513521.

29. Patterson, R. L. and Stevenson, M. H. (1995) Irradiation-induced off-odor in chicken and its possible control. Br. Poult. Sci. 36, 425-441.

30. SAS Institute (1995) SAS/STAT User's Guide. SAS Institute Inc., Cary, NC.

31. Shahidi, F., Yun, J., Rubin, L. J., and Wood, D. F. (1987) The hexanal content as an indicator of oxidative stability and flavor acceptability in cooked ground pork. Can. Inst. Food Sci. Technol. J. 20, 104-106.

32. Sorheim, O., Nessen, H., and Nesbakken, T. (1999) The storage life of beef and pork packaged in an atmosphere with low carbon monoxide and high carbon dioxide. Meat Sci. 52, 157164.

33. World Health Organization (1999) High-dose irradiation: Wholesomeness of food irradiated with doses above $10 \mathrm{kGy}$. WHO Technical Report Series 890. Geneva.

34. Xiong, Y. L., Decker, E. A., Robe, G. H., and Moody, W. G. (1993) Gelation of crude myofibrillar protein isolated from beef heart under antioxidant conditions. J. Food Sci. 58, 1241-1244.

35. Yoshida, H. and Takagi, S. (1999) Antioxidative effects of sesamol and tocopherols at various concentrations in oils during microwave heating. J. Sci. Food Agric. 79, 220-226. 